\title{
FACTORS DETERMINING THE FIRM'S COST OF CAPITAL
}

\author{
Associate Professor PhD Marioara Mirea, E-mail: mm mirea@yahoo.com \\ Lecturer PhD Nicoleta Asalos,E-mail: nicoleta_asalos@yahoo.com \\ Professor PhD Aivaz Kamer Ainur,E-mail: kamer_aivaz@yahoo.com \\ „Ovidius” University Constanta
}

\begin{abstract}
This study is ready to connect the firm's investment decisions with its financing decisions. The cost of capital provides this fundamental connecting link. The term cost of capital may be used interchangeably with the firm's required rate of return, the hurdle rate, the discount rate, and the firm's opportunity cost of funds. This study is about the concepts behind the cost of capital, as well as the procedures for estimating the firm's cost of capital. For the most part, we will assume a constant debt-to-equity mix when computing a company's cost of capital.
\end{abstract}

\section{THE COST-OF-CAPITAL CONCEPT}

The cost of capital is the opportunity cost of using funds to invest in new projects. This is appropriate because the cost of capital is that rate of return on the firm's total investment which earns the required rates of return of all the sources of financing. Furthermore, if the firm earns the investor's required rates of return on all its sources of financing, including that of the common shareholders, then the value of its common stock will not be changed by the investment. By the same reasoning, if the firm earns a rate of return higher than the cost of capital then the excess return will lead to an increase in the value of the firm's common stock and consequently, an increase in shareholder wealth. Thus the logic of using the cost of capital as the hurdle rate for new capital investments can be summarized as follows:

Investment Rate of Return Shareholder Wealth

Internal Rate of Return < Cost of Capital

Decreases

Internal Rate of Return $=$ Cost of Capital

No Change

Internal Rate of Return > Cost of Capital

Increases

Figure 1. Investment and Financing Schedules

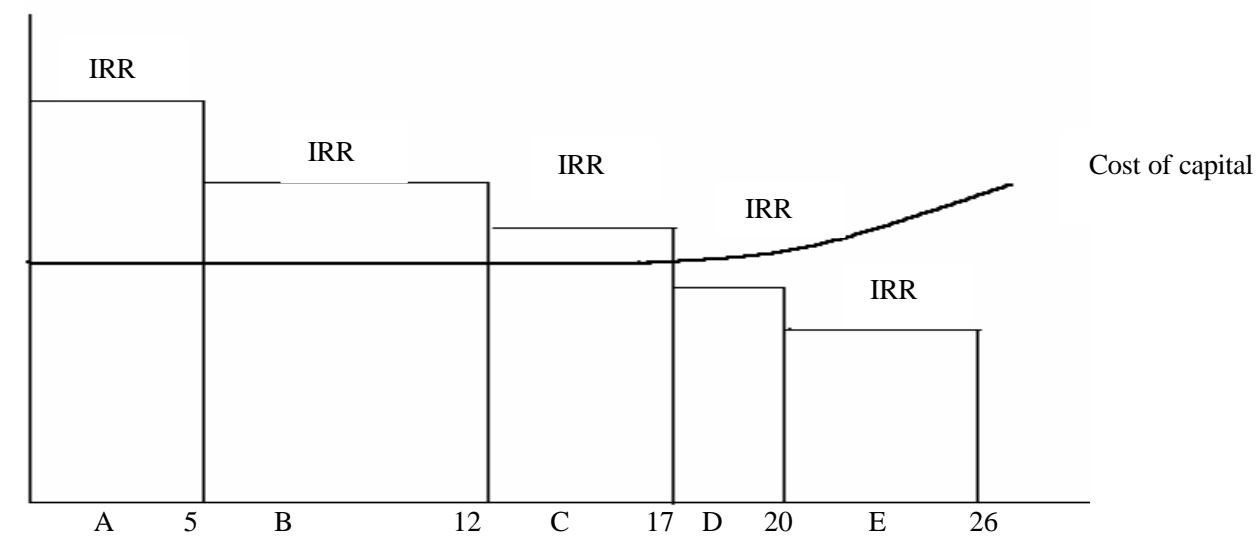

$\mathrm{IRR}=$ Internal rate of return

Financing euro millions

Figure 1 provides an illustration of the use of the cost of capital to determine a firm's capital budget. The internal rates of return on projects A, B, and C exceed the firm's cost of capital and should be 
accepted, whereas projects $\mathrm{D}$ and $\mathrm{E}$ should be rejected. The result is a capital budget equal to 17 million euro. We have made two important assumptions in our analysis thus far, and these should be stated explicitly:

a. We have assumed that all five of the projects in Figure 1 are of equivalent risk. That is, the opportunity cost of capital is the same for all five investments. Obviously, we would not have the same opportunity cost of capital for an investment in short-term Treasury bills and for an investment involving drilling for oil in a politically unstable part of the world.

b. We have assumed that the mix of financing sources-debt relative to equity- remains constant for all investments. The reason for this assumption will become clear when we discuss the calculation of the cost of capital.

Note that Figure 1 holds investment risk constant so that the same required rate of return is appropriate for all investments. This is a direct implication: The Risk-Return Tradeoff-We Won't Take on Additional Risk Unless We Expect to Be Compensated with Additional Return. That is, the cost-of-capital concept represents a "risk-appropriate" rate of return. As the riskiness of the project(s) being considered varies, the "risk-appropriate" cost of capital changes accordingly.

\section{FACTORS DETERMINING THE FIRM'S COST OF CAPITAL}

What are the elements in the business environment that cause a company's weighted cost of capital to be high or low? We identify four primary factors : general economic conditions, the marketability of the firm's securities (market conditions), operating and financing conditions within the company, and the amount of financing needed for new investments.

\section{Factor 1: General Economic Conditions}

General economic conditions determine the demand for and supply of capital within the economy, as well as the level of expected inflation. This economic variable is reflected in the risk less rate of return. This rate represents the rate of return on risk-free investments, such as the interest rate on short-term government securities. In principle, as the demand for money in the economy changes relative to the supply, investors alter their required rate of return. For example, if the demand for money increases without an equivalent increase in the supply, lenders will raise their required interest rate. At the same time, if inflation is expected to deteriorate the purchasing power of the euro, investors require a higher rate of return to compensate for this anticipated loss.

\section{Factor 2: Market Conditions}

When an investor purchases a security with significant risk, an opportunity for additional returns is necessary to make the investment attractive. Essentially, as risk increases, the investor requires a higher rate of return. This increase is called a risk premium. When investors increase the ir required rate of return, the cost of capital rises simultaneously. Remember we have defined risk as the potential variability of returns. If the security is not readily marketable when the investor wants to sell, or even if a continuous demand for the security exists but the price varies significantly, an investor will require a relatively high rate of return. Conversely, if a security is readily marketable and its price is reasonably stable, the investor will require a lower rate of return and the company's cost of capital will be lower.

\section{Factor 3: Operating and Financing Decisions}

Risk, or the variability of returns, also results from decisions made within the company. Risk resulting from these decisions is generally divided into two types: business risk and financial risk. Business risk is the variability in returns on assets and is affected by the company's investment decisions. Financial risk is the increased variability in returns to common stockholders as a result of financing with debt or preferred stock. As business risk and financial risk increase or decrease, the investor's required rate of return (and the cost of capital) will move in the same direction. 


\section{Factor 4: Amount of Financing}

The last factor determining the corporation's cost of funds is the level of financing that the firm requires. As the financing requirements of the firm become larger, the weighted cost of capital increases for several reasons. For instance, as more securities are issued, additional flotation costs, or the cost incurred by the firm from issuing securities, will affect the percentage cost of the funds to the firm. Also, as management approaches the market for large amounts of capital relative to the firm's size, the investors' required rate of return may rise. Suppliers of capital become hesitant to grant relatively large sums without evidence of management's capability to absorb this capital into the business. This is typically "too much too soon". Also, as the size of the issue increases, there is greater difficulty in placing it in the market without reducing the price of the security, which also increases the firm's cost of capital.

\section{A Summary Illustration}

To summarize, the important variables influencing a corporation's cost of capital include the following:

1. General economic conditions. This factor determines the risk-free or riskless rate of return.

2. Marketability of a company's securities: As the marketability of a security increases, investors' required rates of return decrease, lowering the corporation's cost of capital.

3. Operating and financial decisions made by management. If management accepts investments with high levels of risk or if it uses debt or preferred stock extensively, the firm's risk increases. Investors then require a higher rate of return, which causes a higher cost of capital to the company.

4. Amount of financing needed. Requests for larger amounts of capital increase the firm's cost of capital.

\section{Bibliography}

1.Andronic,B.,C.-“ Performanta firmei”, Ed.Polirom,Iasi,2000;

2.Cârstea,Ghe.(coord.)-“Analiza strategica a mediului concurential”,Ed.Economica,Bucuresti,2002;

3.Mironiuc,M.-“Analiza performantelor economico-financiare ale întreprinderii”,Ed.Junimea, Iasi,1999;

4.Thibaut,J.,P.-“Le diagnostic d'entreprise”, les èditions d'Organisation,Paris,1989. 